\title{
The impact of the use of special quality workouts on distinctive strengths speed and density of the bones of metals gave rise to racers high jump \\ Prof. Dr/ Osama Ahmed Mohamed Zaki \\ Introduction and research problem:
}

The world is witnessing a great development in various sports fields and has become to rely on results of scientific research is the basis of access to sports summit levels, and perhaps the sports mutations that we see in international forums Olympic courses best proof of that, and so it became necessary to use the scientific method and its application to the Egyptian sports environment and the private for budding stages, where they represent the core and basis in the upbringing of generations of sports, so that we can access to the international sporting levels. (5: 2)

Khalid Farid Ezzat 2007. It is noteworthy that the quality workouts are workouts geared toward the muscles involved to performance, so that the direction of the dynamic identical to the path of the motor skills learned, and the availability of good examples of these exercises is essential for the success of the training and educational process alike. (5:10)

And confirms (ali elsaid rehan) 2007 that this type of quality workouts serve muscle groups all working in the motor performance where this is in the same direction as the muscle work is used in the performance of movements. (9: 119)

It also adds "Massad ali Mahmoud" (2003) that the quality of the exercises similar performance occupies an important role in education and to improve skill performance and increase the effectiveness of these exercises training should be consistent with the kinetic path of the skill to be training with the participation of the muscles working in the movement, taking into account the gradient from the simple to The most difficult and put the exercises in an orderly manner and sequential in nature. (16: 234)

Indicates Ahmad Ibrahim, amr allah alBisatti 1995 that most of the exercises must be 
conducted in conditions similar to the performance of the motor, where the selection of specific exercises and training on the private motor performance skills is the best way to progress physically and footwork. (5: 2)

Adds Imad Eddin Abdel Fattah (2001) that the use of specific exercises similar performance skills contribute significantly to improve motor skills performance in the competition. (10: 157)

Suggests Thomas and others, et, al (2000) that the development of various sports training programs and planning for loads physical and selection of exercises should include some special and stimulating bone growth workouts, adding that there are some studies that I got to know the effects of different sports on BMD has been identified them and discovered $\mathrm{X}$ and the regions of the body as the pelvis and spine and most influential result of confrontational activities, also adds that the period that stops sports training accompanied by a reduction in bone minerals BMD at rapid rates down calcium, resulting in a loss in BMD also appears after rest and lie down in bed for several weeks, where the spine is affected as a result of the absence of defibrillation operations, advised to maintain bone minerals in the spine during the period of negative quiet standing rest for three hours a day and must take into account when training programs designed to improve bone mass. (22:61)

And asserts, "Roger" (2002) that studies have shown that the best shift of the bones is through the use of physical loads Afattrah which is better than continuous physical loads, moreover, large joints of her strong influence on bone mass of metal. (21: 215)

As also it confirms Roger (2002) to shift the bones reveals its response to the shock loads is the omission of this incentive as an adverse effect on the process of transformation of the bone. (21: 215)

It is noteworthy Hussein Hashmat, Nader Mohammed Shalaby (2003) that the evidence shows that a large proportion of the (body size, components, physical fitness, the length of the skeleton, vulnerable, oceans) be specific genetically and method of measurements in general is a 
method of anthropometric measurements except bone mass, density BMD bone minerals are by radiation anti DEXA. (4:123)

Explains Jones et, al (2003) to physical activities in childhood importance and great benefit to the health, as they have great efficacy on bone mass and at least some of which maintains bone BMD metal density rate in the future and most of the time. (18)

So the researcher believes that the main task of the performance in various Mspaqat jump is to try to jump to the farthest distance or height is possible with the use of every latent powers of the body, jump competition high a jump competitions in athletics, where you need to connect the motor track of parts common body without being located in a contrary path .

This is in addition to the yield, or interest rate applied as a result of this research, which can be reached through the results can guide those in charge of the training process in order to reach the highest levels of digital achievements.

The need for such research has become increasingly urgent as it became necessary to supplement these studies own research to choose the ways and means that can be commensurate with what is required to access the appropriate amounts of power for the production of motor to achieve the highest achievement digital.

The problem with this research as observed by a researcher through his experience and coin and brief him on the national network of information and previous studies and research and permanent monitoring of the evolution of the indices, whether at the national level or at the global level from low digital level at the sports high school students in the high jump competition and the decline in the level attributed Researcher to several reasons, this causes weakness in the distinctive force as quickly as private and do not recognize the human body geometry and how it works in ordinary life, and bone density metals in addition to that it may draw the attention of the researcher most coaches interesting development and strengthen muscles without paying attention to the strengthening of bones that are working on these muscles. So focused researcher idea in the 
development of the proposed training program quality of the training and find out the impact of this program on the distinctive strengths as quickly and as well as BMD in an attempt to improve the quality of these students physically, technically and skill and thus the development of the level of achievement of digital high jump in that age group.

- Research Objectives: The aim of this research is to develop a training program using the special quality of training and knowledge of its effect on the distinctive strengths speed and some metals bone density gave rise to racers high jump at the research sample through: -

1. identify the impact of the proposed training program using the special quality workouts on distinctive strengths speed and level figure the high jump at the research sample.

2. identify the impact of the proposed training program using the special quality training on bone density metals feet raising in the high jump at the research sample.

\section{- hypotheses:}

1. the proposed training program affects the use of special quality workouts a positive impact on the distinctive strengths speed digital level and the high jump at the research sample.

2. The proposed training program affects the use of special quality workouts a positive effect on bone density metals feet raising in the high jump at the research sample.

- Terms used in the research:

* bone density Bone Metal Minerals Density: is the ratio of bone minerals concentration of calcium and phosphorus are an indicator of the hardness of the bone. (23)

* Bone mass of metal Bone Minerals Mass: is the hardness of the bone caused by the presence of minerals ratios. (23)

* Specific Exercises quality training is training that reaches the maximum specialization in performance skills development in quantity and quality and timing in accordance with the uses of momentary muscle or muscle groups within the skill performance. (11: 225) (8.11)

\section{Research procedures: - Research Methodology:}

The researcher used the experimental method using a measuring pre and post experimental design for a trial period of one as it suits the nature of the study. 
The research sample:

was selected sample purposively kidney research community, which numbered (19) Student majoring athletics school, second grade high school sports in Zagazig for the academic year 2014/2015 m sample was tested selection and number (12) students with high digital level in the competition high jump as well as (5) other students to experience the reconnaissance of the same research society were excluded (2) called for irregularities following tables (1), (2), (3), (4) describes the characterization of the homogeneity of the sample in the growth variables and variables physical and digital level under discussion.

Table (1)

sample characterization

\begin{tabular}{|c|c|c|c|c|c|c|c|c|}
\hline \multirow{2}{*}{$\begin{array}{c}\text { The } \\
\text { researc } \\
\text { sample }\end{array}$} & \multicolumn{2}{|c|}{$\begin{array}{c}\text { The research sample } \\
\text { Expeditionary }\end{array}$} & \multicolumn{2}{|c|}{$\begin{array}{c}\text { The research sample } \\
\text { Experimental }\end{array}$} & \multicolumn{2}{|c|}{ Excluded } & \multicolumn{2}{|c|}{$\begin{array}{c}\text { The research } \\
\text { sample college }\end{array}$} \\
\hline & number & $\begin{array}{c}\text { The } \\
\text { ratio } \%\end{array}$ & number & $\begin{array}{c}\text { The } \\
\text { ratio } \%\end{array}$ & numbel & $\begin{array}{c}\text { The } \\
\text { ratio } \%\end{array}$ & number & $\begin{array}{c}\text { The } \\
\text { ratio\% }\end{array}$ \\
\hline $\begin{array}{c}\text { researcl } \\
\text { commy } \\
\text { nity }\end{array}$ & 5 & 26.31 & 12 & 63.16 & 2 & 10.53 & 19 & 100 \\
\hline $\begin{array}{l}\text { that } \\
\text { (19) } \\
\text { expl }\end{array}$ & $\begin{array}{l}\text { Is evide } \\
\text { the rese } \\
\text { dem } \\
\text { oratory }\end{array}$ & $\begin{array}{l}\text { from } \\
\text { h co } \\
\text { led } \\
\text { earch }\end{array}$ & $\begin{array}{l}\text { able } 1 \\
\text { munity } \\
100 \% \text {, } \\
\text { sample }\end{array}$ & $\begin{array}{l}(5) \\
26.3 \\
\text { sam! } \\
\text { And }\end{array}$ & $\begin{array}{l}\text { student } \\
1 \%, \text { exp } \\
\text { le (12) } \\
\text { exclude }\end{array}$ & $\begin{array}{l}\text { ts in } \\
\text { gerime } \\
\text { stude } \\
\text { (2) }\end{array}$ & $\begin{array}{l}\text { ased } b \\
\text { researc } \\
\text { by } 64 \% \\
3 \%\end{array}$ & \\
\hline
\end{tabular}

Table (2)

the total sample homogeneity in growth $n=$ variables (17)

\begin{tabular}{c|c|c|c|c|c}
\hline \hline Variable & measruing uni & SMA & standard deviatiol & Mediato & Sprain \\
\hline \hline Age & Year & 16.29 & 0.99 & 16 & 0.90 \\
\hline Length & $\mathrm{cm}$ & 172.06 & 3.73 & 172 & 0.05 \\
\hline weight & $\mathrm{Kg}$ & 64.59 & 6.71 & 64.90 & -0.14 \\
\hline \hline
\end{tabular}

Is evident from Table (2)

All transactions torsion values for the total sample ranged from (- 0.14: 0.90) in growth variables were confined to these values between $[-3,+3]$ suggesting that the research sample homogeneous in the growth and results of variables representative of the population represented equinoctial . 
Table (3)

College research sample homogeneity in physical tests $n=(17)$

\begin{tabular}{|c|c|c|c|c|c|}
\hline Physical tests & $\begin{array}{c}\text { measruing } \\
\text { unit }\end{array}$ & SMA & $\begin{array}{l}\text { standard } \\
\text { deviation }\end{array}$ & Mediator & Sprains \\
\hline 30-meter dash & second & 3.71 & 0.08 & 3.69 & 0.67 \\
\hline Vertical jump of stability & $\mathrm{cm}$ & 32.14 & 2.67 & 31.22 & 1.03 \\
\hline $\begin{array}{c}\text { Vertical jump of } \\
\text { movement }\end{array}$ & $\mathrm{cm}$ & 41.74 & 2.06 & 41.50 & 0.36 \\
\hline Broad jump of stability & meter & 1.85 & 0.03 & 1.58 & 0.05 \\
\hline Leg strength & $\mathrm{Kg}$ & 134.35 & 5.17 & 136 & -0.96 \\
\hline Level digital high jump & meter & 1.36 & 0.04 & 1.35 & 0.66 \\
\hline $\begin{array}{l}\text { Shown in } \\
\text { that all transac } \\
\text { values for the } \\
\text { ranged from (- } \\
\text { physical varial } \\
\text { values are confin }\end{array}$ & $\begin{array}{l}\text { le } \\
\text { no. (3) } \\
\text { tal sample } \\
\text { 6: } 1.03 \text { ) in } \\
\text { s. These } \\
\text { between [- }\end{array}$ & & $\begin{array}{l}+3] \text { sugg } \\
\text { earch sam } \\
\text { physical } \\
\text { ults repre } \\
\text { ulation } \\
\text { inoctial . }\end{array}$ & $\begin{array}{l}\text { ng that } \\
\text { homogene } \\
\text { bles and } \\
\text { ative of } \\
\text { represen }\end{array}$ & $\begin{array}{l}\text { the } \\
\text { ous } \\
\text { the } \\
\text { the } \\
\text { ited }\end{array}$ \\
\hline
\end{tabular}

\section{Table (4)}

The homogeneity of the sample college in density and mass of variables Metal foot bones upgrade $n=(17)$

\begin{tabular}{l|l|c|c|c|c}
\hline \hline \multicolumn{1}{c|}{ BMD variables } & measruing uni & SMA & $\begin{array}{c}\text { standard } \\
\text { deviation }\end{array}$ & Mediator & Spra \\
\hline \hline Femoral neck bone BMD & $\mathrm{G} / \mathrm{cm} 2$ & 1.11 & 0.05 & 1.11 & -0.23 \\
\hline Greater trochanter BMD & $\mathrm{G} / \mathrm{cm} 2$ & 0.90 & 0.04 & 0.91 & -0.49 \\
\hline Ards triangular bone BMD & $\mathrm{G} / \mathrm{cm} 2$ & 0.81 & 0.03 & 0.81 & 0.44 \\
\hline Femoral neck BMC bone & $\mathrm{G} / \mathrm{cm} 2$ & 4.74 & 0.06 & 4.73 & 0.31 \\
\hline Greater trochanter BMC & $\mathrm{G} / \mathrm{cm} 2$ & 11.80 & 0.05 & 11.78 & 1.18 \\
\hline Ards triangular bone and BMC & $\mathrm{G} / \mathrm{cm} 2$ & 0.86 & 0.03 & 0.86 & 0.47 \\
\hline \hline \\
Shown in Table No. (4)
\end{tabular}

Assiut Journal For Sport Science Arts 
- Medical standards for measuring the balance of the total weight / kg. (Annex 2)

- Flags and cones and signs of an officer.

Boxes of various heights

- A high bounce and casual, mattresses, jumped him.

Almanomitr.

- Measuring a length of $50 \mathrm{~m}$ bar.

Digital clock stopped.

- The number of medical

Dambalz enough balls.

Vests weights of different weights.

- Chalk to draw and measure the broad jump stability

- Aljeter is a cloth bags filled with sand and different weights not exceeding $2 \mathrm{~kg}$.

- Danamumitr device to measure leg strength, back muscles.

- DEXA device anti-ray to measure bone density and mass of metal (BMD, BMC) among a sample search. Attachment No. (7)

Second, the physical tests used in the research:

After reviewing the related topic of research and the various references and scientific studies in specialized tests and standards and in line with the objectives of the research, the researcher suggested a battery of tests to measure the strength characteristic speed in addition to measuring the digital level in high jump competition in accordance with the Act and these tests are:

- 30 meters enemy Facility No. (3)

- alothb perpendicular stability Attachment No. (4)

- vertical jump of the movement

- the broad jump test of fortitude (distinctive strengths speed) poison. Attachment No. (5)

- Test leg strength Baldanamumitr

Attachment No. (6)

Physiological measurements:

- Density and bone mass measurements of metals using the DEXA machine. Attachment No. (7)

* Metal bone density gave upgrade: the density was measured in the following:

- Femoral neck. - The greater trochanter. - (Triangular bone and Ards) Wards Tri

* Metal bone mass feet upgrade: where mass measurement are as follows:

- Femoral neck. - The greater trochanter. - (Triangular bone and Ards) Wards Tri .

\section{Exploratory study:}

Researcher conducted the survey during the period from Sunday 09.21.2014 and till Saturday 27/9/2014 $\mathrm{m}$ and on a sample of (5) students from the research community in order to identify appropriate proposed 
program for the research sample and all the tools used for training as well as to make sure physical tests used have been scientific tests used for transactions account (truthfulness - steadiness) as Next:

\section{truthfulness:}

To calculate truthfulness researcher used the sincerity of

Table (5)

Significance of differences between the two groups is distinctive and special reconnaissance sample In physical tests $n 1=n 2=(5)$

\begin{tabular}{|c|c|c|c|c|c|c|}
\hline \multirow[b]{2}{*}{ Physical tests } & \multirow{2}{*}{$\begin{array}{c}\text { measrui } \\
\text { ng unit }\end{array}$} & \multicolumn{2}{|c|}{$\overline{\text { Distinctive }}$} & \multicolumn{2}{|c|}{ Group unmarked } & \multirow{2}{*}{$\begin{array}{l}\text { Value } \\
\text { "T." }\end{array}$} \\
\hline & & SMA & $\begin{array}{l}\text { Standard } \\
\text { deviation }\end{array}$ & SMA & $\begin{array}{l}\text { Standard } \\
\text { deviation }\end{array}$ & \\
\hline 30-meter dash & second & 3.72 & 0.11 & 4.09 & 0.06 & $6.653^{*}$ \\
\hline $\begin{array}{l}\text { Vertical jump } \\
\text { of stability }\end{array}$ & $\mathrm{cm}$ & 31.19 & 1.83 & 25.6 & 2.77 & $3.755^{*}$ \\
\hline $\begin{array}{l}\text { Vertical jump } \\
\text { of movement }\end{array}$ & $\mathrm{cm}$ & 41.11 & 2.06 & 34.98 & 1.98 & $4.793^{*}$ \\
\hline $\begin{array}{l}\text { Broad jump of } \\
\text { stability }\end{array}$ & meter & 1.84 & 0.03 & 1.30 & 0.16 & $7.496^{*}$ \\
\hline Leg strength & $\mathrm{Kg}$ & 136.2 & 5.26 & 124.80 & 4.44 & $3.703^{*}$ \\
\hline $\begin{array}{l}\text { Level digital } \\
\text { high jump }\end{array}$ & meter & 1.37 & 0.04 & 1.25 & 0.03 & $4.964^{*}$ \\
\hline
\end{tabular}

The value of "T" Driven at 0.05 and 8 degrees of freedom $=2306$

Shown in Table No. (5) and no statistically significant differences in the physical tests under discussion between each of the distinctive group and is distinctive and in favor of distinctive Group, as the value of the "T" calculated exceeded the value of "T" Driven at the moral level of 0.05 , and the differentiation between the two groups, one characteristic of the research community and outside the core sample and the number (5) students and the other is characteristic of firstgrade students of high school sports and the number (5) students as shown in Table 5. 
Table (6)

Between the first and second application of the sample correlation coefficient Exploratory in physical tests $n=(5)$

\begin{tabular}{|c|c|c|c|c|c|c|}
\hline \multirow{2}{*}{$\begin{array}{c}\text { Physical } \\
\text { tests }\end{array}$} & \multirow{2}{*}{$\begin{array}{l}\text { measruin } \\
\text { g unit }\end{array}$} & \multicolumn{2}{|c|}{ The first application } & \multicolumn{2}{|c|}{$\begin{array}{l}\text { The second } \\
\text { application }\end{array}$} & \multirow{2}{*}{$\begin{array}{l}\text { Value } \\
\text { "R." }\end{array}$} \\
\hline & & SMA & $\begin{array}{l}\text { standard } \\
\text { deviation }\end{array}$ & SMA & $\begin{array}{l}\text { standard } \\
\text { deviation }\end{array}$ & \\
\hline $\begin{array}{l}\text { 30-meter } \\
\text { dash }\end{array}$ & second & 3.72 & 0.11 & 3.70 & 0.09 & $0.898^{*}$ \\
\hline $\begin{array}{l}\text { Vertical } \\
\text { jump of } \\
\text { stability }\end{array}$ & $\mathrm{cm}$ & 31.19 & 1.83 & 33.1 & 1.40 & $0.971^{*}$ \\
\hline $\begin{array}{l}\text { Vertical } \\
\text { jump of } \\
\text { movement }\end{array}$ & $\mathrm{cm}$ & 41.11 & 2.06 & 39.34 & 2.23 & $0.890^{*}$ \\
\hline $\begin{array}{l}\text { Broad jump } \\
\text { of stability }\end{array}$ & meter & 1.84 & 0.03 & 1.87 & 0.05 & $0.853^{*}$ \\
\hline Leg strength & $\mathrm{Kg}$ & 136.20 & 5.26 & 139.5 & 4.87 & $0.892^{*}$ \\
\hline $\begin{array}{l}\text { Level digital } \\
\text { high jump }\end{array}$ & meter & 1.37 & 0.04 & 1.35 & 0.06 & $0.968^{*}$ \\
\hline
\end{tabular}

The value of " $t$ " Driven at 0.05 and 3 degrees of freedom $=0.878$

Shown in Table No. (6) there is a statistically significant between each of the research sample exploratory degrees of correlation in the first application of the tests of physical and degrees of the second application for the same group reconnaissance interval time frame as the value of the correlation coefficient calculated exceeded Tabulated value at the moral level of 0.05 degrees freedom 4, which means stability of test scores when re-applied under the same conditions again.
- The proposed training program: Attachment No. (8) It reminds both"Talha Hossam El Din" (1997), "Mohammad Abdul Rahim Ismail" (1998), and " Flikck, Kramer" (2004 m) muscle strength does not develop quickly and that training for several weeks contribute to development and developed, and the period (8) training weeks time enough to get to the amount of the characteristic force as quickly as can be measured and inferred They also pointed out that the training time (module) ranges between 60: 90 minutes and that was enough time within 
the limits of the total number of weeks mentioned above. (6: 180), (14:41), (17: 129)

Based on that the researcher select the application program (8) A training weeks by 4 training units per week is long enough to achieve the goal of research.

$$
\text { Indicates "Abul-Ela }
$$

Ahmed Abdel Fattah, Ahmed Syed Naseeruddin" (2003 to be trained as quickly as distinctive force ranges between $40-80 \%$. (1: 122)

Based on that the researcher select the application program (8) A training weeks by 4 training units per week is long enough to achieve the goal of research.

Training load for the
proposed program
components:
$*$ Load intensity: indicates
"Abul-Ela Ahmed Abdel Fattah, Ahmed Naseer elddin said" (2003) indicate that maximum security is from 40 $80 \%$ of the maximum what the individual can tolerate during exercise distinctive strengths speed. (1: 122)

Therefore, the researcher took into account not increase the intensity of the training program for $80 \%$ of the maximum an individual can afford.

* Pregnancy size: After reviewing some of the literature that I talked in this regard, the researcher took into account that the number of iterations commensurate with the severity used in the exercise, including not lead to the occurrence of the phenomenon of overload, where the number of times ranged repeat the exercise in the program from 8-10 repeating groups of 3-5 sets. (1) (17)

\section{- Intra rest periods:}

Raa researcher to be a two-way breaks the extent that it allows the return of the organs of the body to its natural state.

The division of module parts:

- Warm-up: Warm-up in this part aims to the arrival of players to the full configuration of the performance of physical and skill exercises necessary for the development of functional efficiency, has taken into account the researcher in this exercise to work to create the joints and ligaments to work and lengthen the muscles working and the creation of cardio respiratory, nervous system that ranges this time part of the (10-15) minutes.

- The main part: contains this part of the training module on functional exercises, which achieve the goal of the training unit, which contributes to the development of physical capacities for selected tests for measurements of physiological under discussion ranges this part of the (40-70) minutes of time kidney unit training. 
- Concluding part: It contains exercises given after the previous exercise with a view to the progressive decline the number of heart to a specific number to help the player to restore the healing and the occurrence of adjustment efforts of training operations. The researcher defined the time of this part of 5:10 minutes, according to the severity of pregnancy inside the main part of the training module.

- Implement search experience: -

- Tribal Measurements: ojerit tribal measurements of variables physical Racecourse Stadium Zagazig University and on Monday, 9/29/2014 m, while for measuring bone spine BMD (paragraphs selected) have been conducted on Tuesday, 30/9/2014 $\mathrm{m}$ and has Department Radiology, Faculty of Medicine Zagazig University by DEXA device anti-ray.

- The application of the training program: The proposed training program applied to the research sample during the period from Saturday 10/4/2014 till Wednesday 26/11/2014 m any length (8) training weeks by 4 units per week under the supervision of Researcher ranges module of time (60-90 minutes).

\section{-Dimensional Measurements:}

After the completion of the application of the training program, the researcher conducted a measurement Posterior in the order and conditions of tribal measurements were made physical measurements on Saturday 29/11/2010 m, while for measuring bone spine BMD (paragraphs selected) were held on Sunday corresponding to $30 / 11 / 2010 \mathrm{AD}$ and has Radiology, Faculty of Medicine Zagazig University by DEXA device anti-ray.

\section{Statistical treatments:}

It was used the following statistical treatments:

- SMA - Torsion coefficient.

- standard deviation.

- Mediator. - Test "T"

- the correlation coefficient

- the proportion of percentage improvement. The adoption of the researcher level of moral .05 limit for statistical significance.

- discuss and display the results:

First: Results: - 
Table (7)

Significance of differences between the measurement pre and post experimental sample In physical tests $n=(12)$

\begin{tabular}{|c|c|c|c|c|c|c|c|}
\hline \multirow{2}{*}{$\begin{array}{c}\text { BMD } \\
\text { variables }\end{array}$} & \multirow{2}{*}{$\begin{array}{c}\text { measrui } \\
\text { ng unit }\end{array}$} & \multicolumn{2}{|c|}{$\begin{array}{c}\text { Measurement } \\
\text { tribal }\end{array}$} & \multicolumn{2}{|c|}{$\begin{array}{c}\text { Measurement } \\
\text { Telemetric }\end{array}$} & \multirow{2}{*}{$\begin{array}{c}\text { Average } \\
\text { The } \\
\text { difference }\end{array}$} & \multirow{2}{*}{$\begin{array}{l}\text { Value } \\
\text { "T." }\end{array}$} \\
\hline & & SMA & $\begin{array}{l}\text { standard } \\
\text { deviation }\end{array}$ & SMA & $\begin{array}{l}\text { standard } \\
\text { deviation }\end{array}$ & & \\
\hline $\begin{array}{c}\text { 30-meter } \\
\text { dash }\end{array}$ & second & 3.70 & 0.07 & 3.47 & 0.06 & 0.23 & $9.523^{*}$ \\
\hline $\begin{array}{l}\text { Vertical } \\
\text { jump of } \\
\text { stability } \\
\end{array}$ & $\mathrm{cm}$ & 32.53 & 2.93 & 41.43 & 2.94 & 8.90 & $9.055^{*}$ \\
\hline $\begin{array}{c}\text { Vertical } \\
\text { jump of } \\
\text { movement }\end{array}$ & $\mathrm{cm}$ & 42.01 & 2.09 & 48.05 & 1.45 & 6.04 & $8.213^{*}$ \\
\hline $\begin{array}{c}\text { Broad jump } \\
\text { of stability }\end{array}$ & meter & 1.86 & 0.03 & 2.02 & 0.05 & 0.17 & $8.018^{*}$ \\
\hline Leg strength & $\mathrm{Kg}$ & 133.58 & 5.16 & 154.42 & 6.07 & 83.02 & $10.381^{*}$ \\
\hline $\begin{array}{c}\text { Level } \\
\text { digital high } \\
\text { jump }\end{array}$ & meter & 1.35 & 0.04 & 1.53 & 0.04 & 0.17 & $8.684^{*}$ \\
\hline
\end{tabular}

The value of "T" Driven at 0.05 and 11 degrees of freedom $=2201$

Shown in Table No. (7) and no statistically significant differences in the physical tests under discussion between each of the measurement tribal and telemetric and in favor of

Table (8)

The percentage improvement in physical tests under discussion

\begin{tabular}{l|c|c|c}
\hline \multirow{2}{*}{\multicolumn{1}{c}{ Physical variables }} & \multicolumn{2}{|c|}{ Core Group } & \multirow{2}{*}{ Ratio improvement } \\
\cline { 2 - 4 } & $\begin{array}{c}\text { Average } \\
\text { tribal }\end{array}$ & $\begin{array}{c}\text { Average } \\
\text { post test }\end{array}$ & \\
\hline \hline 30-meter dash & 3.70 & 3.47 & $6.22 \%$ \\
\hline Vertical jump of stability & 32.53 & 41.43 & $27.36 \%$ \\
\hline Vertical jump of movement & 42.01 & 48.05 & $14.38 \%$ \\
\hline Broad jump of stability & 1.86 & 2.02 & $8.60 \%$ \\
\hline Leg strength & 133.58 & 154.42 & $15.60 \%$ \\
\hline Level digital high jump & 1.35 & 1.53 & $13.33 \%$ \\
\hline \hline
\end{tabular}


Shown in Table No. (8) the existence of differences in the percentages of improvement between the two measurements pre and post experimental group in all the physical tests and digital level in question, where the highest differences in improvement rates in test vertical jump of the Stability and amounted to $27.36 \%$ and was less difference in improvement rates in a test of 30 -meter dash and amounted to $6.22 \%$.

Table (9)

Significance of differences between the measurement pre and post experimental sample in variables Metal bone density gave upgrade $n=(12)$

\begin{tabular}{|c|c|c|c|c|c|c|c|}
\hline \multirow{2}{*}{$\begin{array}{c}\text { BMD } \\
\text { variables }\end{array}$} & \multirow{2}{*}{$\begin{array}{c}\text { measru } \\
\text { ing } \\
\text { unit }\end{array}$} & \multicolumn{2}{|c|}{ Measurement tribal } & \multicolumn{2}{|c|}{$\begin{array}{c}\text { Measurement } \\
\text { Telemetric }\end{array}$} & \multirow{2}{*}{$\begin{array}{c}\text { Average } \\
\text { The } \\
\text { difference }\end{array}$} & \multirow{2}{*}{$\begin{array}{l}\text { Value } \\
\text { "T." }\end{array}$} \\
\hline & & SMA & $\begin{array}{c}\text { standard } \\
\text { deviation }\end{array}$ & SMA & $\begin{array}{c}\text { standard } \\
\text { deviation }\end{array}$ & & \\
\hline $\begin{array}{c}\text { Femoral neck } \\
\text { bone BMD }\end{array}$ & $\mathrm{g} / \mathrm{cm} 2$ & 1.11 & 0.05 & 1.30 & 0.04 & 0.19 & $\begin{array}{c}11.056 \\
*\end{array}$ \\
\hline $\begin{array}{c}\text { Greater } \\
\text { trochanter } \\
\text { BMD }\end{array}$ & $\mathrm{g} / \mathrm{cm} 2$ & 0.90 & 0.04 & 0.96 & 0.03 & 0.06 & $6.063^{*}$ \\
\hline $\begin{array}{c}\text { Ards } \\
\text { triangular } \\
\text { bone BMD }\end{array}$ & $\mathrm{g} / \mathrm{cm} 2$ & 0.82 & 0.03 & 0.93 & 0.04 & 0.11 & $\begin{array}{c}10.641 \\
*\end{array}$ \\
\hline
\end{tabular}

The value of "T" Driven at 0.05 and 11 degrees of freedom $=2201$

Shown in Table No. (9) and no statistically significant differences in the metals bone density variables differences presented upgrading under discussion between each of the tribal measurement and telemetric and in favor of telemetric the experimental research sample, as the value of the "T" calculated exceeded the value of "T" spreadsheet when 0.05 level of significance, the degree of freedom of 11 . 
Table (10)

The percentage improvement in bone density metals variables Foot upgrade under discussion

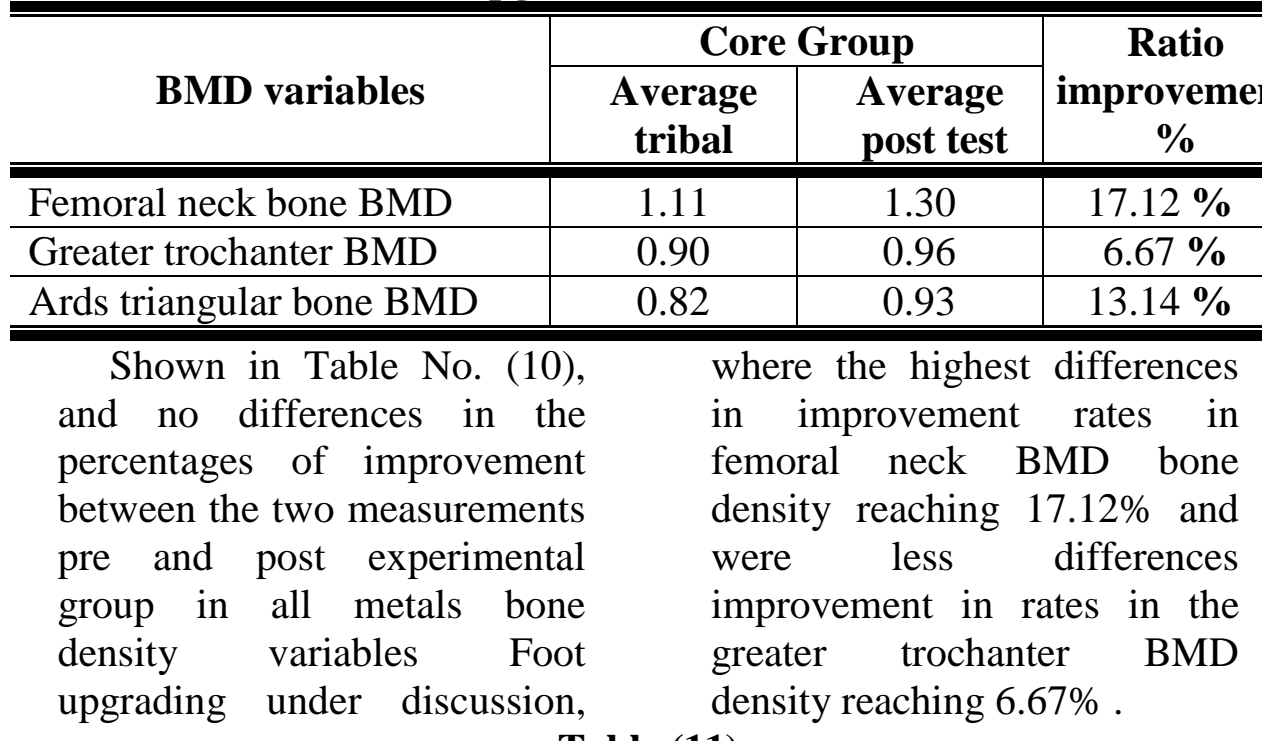

Table (11)

Significance of differences between the measurement pre and post experimental sample in variables Bloc metals bones Foot raising $\mathbf{n}=\mathbf{( 1 2 )}$

\begin{tabular}{|c|c|c|c|c|c|c|c|}
\hline \multirow{2}{*}{$\begin{array}{c}\text { Bone mass } \\
\text { metals } \\
\text { variables }\end{array}$} & \multirow{2}{*}{$\begin{array}{c}\text { meas } \\
\text { ruing } \\
\text { unit }\end{array}$} & \multicolumn{2}{|c|}{$\begin{array}{c}\text { Measurement } \\
\text { tribal }\end{array}$} & \multicolumn{2}{|c|}{$\begin{array}{c}\text { Measurement } \\
\text { Telemetric }\end{array}$} & \multirow{2}{*}{$\begin{array}{c}\text { Average } \\
\text { The } \\
\text { difference }\end{array}$} & \multirow{2}{*}{$\begin{array}{l}\text { Value } \\
\text { "T." }\end{array}$} \\
\hline & & SMA & $\begin{array}{l}\text { standard } \\
\text { deviation }\end{array}$ & SMA & $\begin{array}{l}\text { standard } \\
\text { deviation }\end{array}$ & & \\
\hline $\begin{array}{c}\text { Femoral neck } \\
\text { bone BMC }\end{array}$ & $\mathrm{g}$ & 4.74 & 0.05 & 5.37 & 0.21 & 0.63 & $11.687^{*}$ \\
\hline $\begin{array}{l}\text { Greater } \\
\text { trochanter } \\
\text { BMC }\end{array}$ & g & 11.79 & 0.05 & 12.06 & 0.21 & 0.26 & $3.930^{*}$ \\
\hline $\begin{array}{c}\text { Ards } \\
\text { triangular } \\
\text { bone and } \\
\text { BMC }\end{array}$ & $\mathrm{g}$ & 0.86 & 0.03 & 0.97 & 0.03 & 0.11 & $7.364^{*}$ \\
\hline
\end{tabular}

Shown in Table No. (11) and no statistically significant differences in the mass of metal bones of variables differences Foot upgrading under discussion between each of the tribal measurement and telemetric and in favor of telemetric the experimental research sample, as the value 
of the "T" calculated exceeded the value of "T" spreadsheet when 0.05

level significance, the degree of freedom of 11 .

Table (12)

The percentage improvement in the metal mass of variables Bones of the Foot improve under discussion

\begin{tabular}{|c|c|c|c|}
\hline \multirow[b]{2}{*}{ Bone mass metals variables } & \multicolumn{2}{|c|}{ Core Group } & \multirow{2}{*}{$\begin{array}{c}\text { Ratio } \\
\text { improvement } \\
\% \\
\end{array}$} \\
\hline & $\begin{array}{c}\text { Average } \\
\text { tribal }\end{array}$ & $\begin{array}{c}\text { Average } \\
\text { post test }\end{array}$ & \\
\hline Femoral neck BMC bone & 4.74 & 5.37 & $13.29 \%$ \\
\hline Greater trochanter BMC & 11.79 & 12.06 & $2.29 \%$ \\
\hline Ards triangular bone and BMC & 0.86 & 0.97 & $13.79 \%$ \\
\hline
\end{tabular}

It is shown in Table No. (12), and no differences in the percentages of improvement between the two measurements pre and post experimental group in all the block variables metals bones Foot upgrade under discussion, where the highest differences in improvement rates in a block bone and Ards triangular BMC reaching $13.79 \%$ and were less differences improvement in rates in the greater trochanter BMC mass, reaching $2.29 \%$.

Second, discuss the results:

First, discuss the results of the first goal:

Shown in Table No. (7) and private in terms of the differences between the measurement pre and post in the physical tests function on the distinctive strengths as quickly and as well as the digital level high jump, there are significant differences between the two measurements pre and post in favor of telemetric in all the physical variables selected under study at the significance level (0.05) and the degree of freedom of 11 experimental group under discussion.

The researcher attributed the reason for the existence of such differences to the positive impact of the proposed program of using qualitative training and who had an active role in improving physical function tests the distinctive strengths speed digital and high-level jump experimental group under discussion.

This is in line with the findings of Ahmed Ibrahim, Assiut Journal For Sport Science Arts 
amr allah elBisatti 1995 (2) where they reached that the choice of specific exercises and training on the private motor performance skills is the best way to progress physically and footwork. (5: 2)

And is also consistent with the findings of the "Ahmed Ali Hussein," (2006) (3), Adel Gouda Abdel Aziz "(2007) (7) where he reached the Training Program using qualitative training led to the development of the physical abilities and performance skills among a sample search.

It is clear from Table (8) the existence of differences in the percentages of improvement between the two measurements pre and post experimental group in all the physical tests function on the distinctive strengths speed digital and high level jump experimental group in question, where the highest differences in improvement rates in test vertical jump of the Stability and reached $27.36 \%$ were less differences in improvement rates in the test 30 meter dash and amounted to $6.22 \%$ and also achieved a vertical jump of motion ratio improved amounted to $14.38 \%$ jump broad stability $8.60 \%$ and also the leg strength of $15.6 \%$ while the improvement ratio in the digital level in high jump $13.33 \%$ due researcher reason for the improvement was attributed to the positive impact of the proposed program of exercises using qualitative and who had an active role in improving physical function tests the distinctive strength and speed as well as the digital level in high jump experimental group under discussion.

This is in line with the findings of both of Imad Eddin Abdel Fattah (2001) (10), "Massad ali Mahmoud" (2003), Adel Gouda Abdel Aziz "(2007) (7) where reach these researchers that the quality of training led to a lineage improvement in physical variables and areas under their research skills.

Through what has been displayed in tables No. (7) and Table (8) possible, the researcher achieved the first goal and confirm the first hypothesis which states that "the proposed training program affects the use of special quality workouts a positive impact on the distinctive strengths speed digital level 
high jump with individuals The research sample".

Second, discuss the results for the second goal:

Shown in Table No. (9) and no statistically significant in all function variables differences metals bone density gave upgrade under discussion between each of the tribal measurement and telemetric and in favor of telemetric the experimental research sample, as the value of the " $T$ " calculated exceeded the value of "T. "Driven at the moral level of 0.05 , and 11 degrees of freedom.

The researcher attributed the cause of the existence of such differences to the impact of the proposed training program using qualitative exercises, which had a positive impact in increasing bone density metals feet BMD upgrade the research sample.

This is consistent with what indicated to him " Roger" (2002) (21) that stimulate bone growth is through physical activities because of their impact on the skeleton as one of the ways to stimulate bone growth.

Both " Obradavic Kovacev" also reached (2005) (20) that there had been an increase in bone minerals in BMD parties used by athletes in the physical activity intensity.

It is clear from Table (10) the existence of differences in the percentages of improvement between the two measurements pre and post experimental group in all metals bone density variables presented upgrading under discussion, where the highest differences in improvement rates in femoral neck BMD bone, reaching $17.12 \%$ intensity and were less differences improvement in rates in the greater trochanter BMD density as $6.67 \%$ and also record and Ards triangular bone BMD 13.14\%

This is because the researcher why there are these differences to the impact of the proposed training program using qualitative exercises, which had a positive impact in improving bone density metals feet BMD upgrade the research sample.

This is consistent with the findings of the "Kelley et al" (2000) (19) that the sports training led to improved BMD by $2.6 \%$, and also with the findings of both the " Obradovi Kovacev" (2005) (20 ) that 
there had been improvement in metals bone density parties used in the exercises in athletes.

Shown in Table No. (11) and no statistically significant in all function on the block metals bones variables differences presented upgrading under discussion between each of the tribal measurement and telemetric and in favor of telemetric the experimental research sample, as the value of the "T" calculated exceeded the value of "T. "Driven at the moral level of 0.05 , and 11 degrees of freedom.

The researcher attributed the cause of the existence of such differences to the impact of the proposed training program using qualitative exercises, which had a positive impact in increasing bone mass metals feet BMC upgrade the research sample.

This is consistent with the findings of the Jones, et, al (2003) (18) that the physical activities have a great efficacy on bone mass and at least some of which preserves the density and bone mass metals BMD rate in the future and most of the time.
And also consistent with the findings of the Tomas, et, al (2000) (22) that the development of sports training programs accompanied by a lifting of the BMD bone density metals at rapid rates.

It is clear from Table (12), and no differences in the percentage of improvement between the two measurements pre and post experimental group ratios in all mass variables metals bones foot upgrading $\mathrm{BMC}$ under discussion, where the highest differences in improvement rates in a block bone and Ards triangular $\mathrm{BMC}$ reaching $13.79 \%$ and were less differences improvement in rates in the greater trochanter BMC mass where $2.29 \%$ and also scored femoral neck BMC13.29\%

This is because the researcher why there are these differences to the impact of the proposed training program using qualitative exercises, which had a positive impact in improving bone mass metals feet BMC upgrade the research sample.

The consistent results of this study with the findings of both Kelley, et, al (2000) (19), Mohammed Abdulaziz elsaid. (2007) (15) where the researchers said that the use of exercise leads to improved density and mass of bone minerals. 
In this regard, it mentions Jones, et, al (2003) (18) that the physical activities of importance and great benefit to health as they have on the effectiveness of the density and mass of bone minerals.

Through what has been displayed in the tables of (912), it was possible for the researcher achieve the second goal and ensure the validity of the second hypothesis which states that "the proposed training program affects the use of special quality workouts a positive impact on metals bone density foot raise in the high jump in a sample members search .

\section{.Conclusions}

and

\section{recommendations:}

First conclusions:

In a sample of research and training program proposed using special quality workouts limits and in the light of the results referred to researcher reached the following conclusions:

1. The proposed training program using the special quality workouts a positive impact in terms of the distinctive moral force as fast in high jump at the research sample.

2. The proposed training program using specific exercises a positive impact in terms of morale on the digital

\section{Assiut Journal For Sport Science Arts}

level in the high jump competition at the research sample.

3. The proposed training program using specific exercises a positive impact in terms of morale on the density and mass of metal foot bones upgrade in the high jump at the research sample.

\section{Second Recommendation: -}

In light of the findings and conclusions researcher recommends the following: 1 - the application of the proposed program using qualitative exercises own because of its impact on the level racers jump as its importance in the development of physical variables and digital level.

2 - The application of the proposed program using qualitative exercises own because of its importance in improving the density and mass of metal foot bones upgrade.

3. Carry out similar studies on other Sunni stages.

4 - The need to put athletics coaches in their training (quality workouts).

\section{References:}

First: The Arabic references: 1. Abul Ela Abdel Fattah, Ahmed Nasre elddin: 
Physiology fitness, 2nd Floor, Dar Arab Thought, Cairo, 2003.

\section{Ahmed Mahmoud} Ibrahim, amr Allah Ahmed elBisatti: the effect of directing loads of training according to the pattern of biorhythm on the values of some functional signs and the level of performance skills and international mobility of the sentence to the player karate, a scientific journal, Physical Education College, No. 32, Alexandria University, 1995.

3. Ahmed Ali Hussein: the effectiveness of a program of exercises specific to certain physical capabilities and variables physiological and their relationship to the level of performance skills of basketball players rookies, Physical Education Research Journal, Vol. 40, No. 76, College of Physical Education, Benin, Zagazig University, December 2007.

4. Hussein Hashmat, nader Shalaby: Genetics in physical education, book publishing center, Cairo, 2003.

5. Khaled fared Ezzat: the impact of the quality of exercises for the development of interoperability capabilities to some semblance of attention and level of technical performance of emerging judo program, doctoral thesis, published, Faculty of Physical Education, Mansoura University, 2007.

\section{Talha Hossam El-Din and} others: scientific encyclopedia in Sport Training, Part I, Dar Arab Thought, Cairo, 1997.

7. Adil goda Abdul Aziz : effectiveness of the training program on qualitative own physical abilities and skill level of some renderings of the basketball players, Ph.D. thesis, unpublished, Faculty of Physical Education for Boys, Zagazig University, 2007.

8. Adel Abdul Basir ali : training ring (foundations and applications), United library for printing and publishing, Port Fouad, 1994.

9. ali elsaid rehan : fitness for Boys culture, i 1, modern library for publication, Mansoura, 2007.

\section{Imad Eddin Abdel Fattah} elserse : the impact of a training program in physical and skill attributes specific to the development of karate players, Ph.D. thesis, unpublished, Faculty of Physical Education, Tanta University, 2001. 
11. Qassim Hassan Hussein: sports and physical encyclopedia overall in games and sporting events, science, $\mathrm{i}$ 1, Dar Arab Thought, Cairo, 1998.

\section{Mohammed Ibrahim} Shehata: Ground Gymnastics guide and horse jumping, art for printing and publishing, Alexandria, 1987.

\section{Sobhy Mohamed}

Hassanein: Measurement and Evaluation in Physical Education and Sports, i 4, Dar Arab Thought, Cairo, 2001.

14. Mohammed Abdul Rahim Ismail: muscle strength training and weightlifting programs, facility knowledge, Alexandria, 1998.

\section{Mohammed Abdulaziz} elsaid : The effect of training on bone Albleomtry metals and some physical abilities and level digital density rider long jump, Master Thesis, Faculty of Physical Education for Boys, Zagazig University, 2007.

\section{Massad Ali Mahmoud:} Encyclopedia of Romania wrestling and free amateur, Daraketb, nationalism, Mansoura, 2003
17. Flikck SJ, Kramer : Dsigning Resistance Training program 3rd ed Human kinetics cham paing, Newyork, USP, 2004.

18 . Jones, et, al :Effects of physical activity on cartilage development in health, Kids, 2003.

19. Kelley et al: Exercise and bone: minerals density in men ameta analysis, Journal of applied Physilogy, vol 88, Lssues May 2003.

20. Obradovic Kovacev : Bone Minerals density of calcaneus and dominat lower limb, faculty of Physical education, University of Novisad, SCG,2005.

21. Roger A.:

Neuromecthanics of human morment third edition ,Human Kinetic, 2002.

22.Thomas R. Beachle, et. al : Essentials of strength training and conditioning second edition, human kinetics, 2000. 23. www.answers.com/topic/ chemistry.

24. www.knol.google.com/k/-//dtif94m4p4a4/sjsvv0/pictur.gi $\mathrm{f}$ 